\title{
Submission or subversion: survival and resilience of Chinese international research students in neoliberalised Australian universities
}

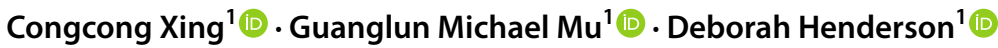

Accepted: 11 October 2021 / Published online: 26 October 2021

(c) Crown 2021

\begin{abstract}
Although scholars have noted the detrimental nature of the various changes in higher education prompted by neoliberalism, its impact on the experiences of international Higher Degree by Research (HDR) students has yet to be adequately studied. Informed by Bourdieu's concepts of doxa, field, habitus, and capital, this paper examines the ways in which neoliberalism as doxa in the Australian higher education field has colonised the perception and practice of Chinese international HDR students whilst some students were able to demonstrate resilience to the pervasive neoliberal practices. The paper draws on a larger qualitative research project including interviews with 18 Chinese HDR students from four Australian universities. Data suggest that Chinese HDR research students gradually developed intensified dispositions of self-reliance and self-exploitation in response to neoliberal academic practices whilst others were enculturated into a floating habitus (or vulnerable position) in relation to academic publishing as they attempted to negotiate the tensions across fields and over time. Data further reveal that some participants demonstrated resilience to neoliberalism when empowered by their supervisors with less utilitarian and more critically reflexive supervisory practices. The paper argues that the embrace of neoliberalism in the Australian higher education field has become widespread yet controversial, and that thinking and enacting resilience sociologically may de-neoliberalise the higher education field in Australia and beyond.
\end{abstract}

Keywords Neoliberalism · International research students $\cdot$ Resilience $\cdot$ Bourdieu · Floating habitus

\section{Introduction}

Since the 1980s, Australian higher education systems have been transformed by neoliberalism (Bottrell \& Manathunga, 2019). Following the withdrawal of government funding and the attendant fee deregulation for higher education, neoliberal managerialist practices

Congcong Xing

congcong.xing@hdr.qut.edu.au

1 School of Teacher Education \& Leadership, Queensland University of Technology, Victoria Park Road, Kelvin Grove, QLD 4059, Australia 
within the sector have increasingly focused on securing efficiency, encouraging competition, and intensifying accountability (Rea, 2016). Concomitantly, Australian higher education continues to shift its core functions of teaching, research, and service to revenue generating operations (Bottrell \& Manathunga, 2019). This focus on revenue raising foregrounds the proliferation of international education in Australia, and prior to the outbreak of COVID-19, deregulated international course fees had become a critical and reliable source of university income (see DET, 2019).

Whilst supporters of the neoliberal university argue that massification and marketisation facilitate greater access to higher education and generate economic benefits to universities and their graduates, many scholars have noted the detrimental nature of those changes prompted by the neoliberalisation of higher education (Rousseau, 2020). As neoliberal logic renders knowledge into a commodity, it prompts an emphasis on competition, measurement, assessment, and economic-driven outcomes (Saunders, 2007). This emphasis has transformed higher education institutions into sites that serve the needs of governments and industries as they are required to actively pursue new revenue streams and new customers (Dougherty $\&$ Natow, 2020). As a form of 'all-invasive governmentality' (Cannella \& Koro-Ljungberg, 2017, p. 155), neoliberalism can be understood as a means of disempowering academics by eroding their autonomy through financial cuts, increased workloads, and performance management practices (Kenny, 2018). Yet how this neoliberal trend impacts on university students' lives and careers has been underexplored, and there is little empirical investigation of international research students' perceptions of their research experience in the neoliberal Australian university. This is despite the fact that such student cohorts constitute a significant group of knowledge users and producers in higher education (Bentley \& Meek, 2018). It is therefore important to identify and consider their experiences in, and responses to, the neoliberal university in current times.

In Australia, the official term of Higher Degree by Research (HDR) denotes research only degrees such as Masters by Research (1.5-2 years full time) and Doctorates (3-4 years full time) (Bentley \& Meek, 2018). During their HDR journey, students are required to complete an independent research project following the standardised milestones including Confirmation, the Mid-candidature Review/Progress Review, and the Pre-submission Seminar/Final Review (TEQSA, 2021). Our paper focuses on the experiences of international HDR students from China, the most prominent international HDR student body on Australian university campuses, which accounts for approximately $14.5 \%$ of the overall Australian HDR students community in 2015 (DESE, 2015). The paper investigates: What are Chinese international HDR students' experiences of, and responses to the neoliberal logic of Australian universities? To answer this question, we conducted interviews with 18 Chinese international HDR students (16 PhDs and 2 Masters) from four Australian universities. Informed by Bourdieu's sociology, we analysed the systemic impact of neoliberalism upon participants' perceptions of research in the academy and the nature of their resilient responses to the prevalence of neoliberalism in Australian universities.

\section{Neoliberalisation and internationalisation of higher education}

Prior to the 1980s, the initial rationale for the internationalisation of Australian universities was based on considerations of 'goodwill, assistance, and Australia's status, and responsibilities, as a first-world nation' (Welch, 2012, p. 295). However, as neoliberal practices increasingly permeate education policy and practice, universities are no longer viewed 
in terms of collaborative endeavours that promote humanistic goals (Saunders, 2007) but rather driven by a market-based economism (Monbiot, 2017). As Giroux (2015) puts it, higher education is now predicated on a business model, treating people as consumers, and capital as the only subject. At the individual level, education has been reconceptualised as a product or service that students can purchase for their own gains (Saunders, 2007). For example, an international student can utilise the opportunity to study in a different country as a strategy for advancing their social mobility through internationalising their studies, curriculum vitae, and social networks (Basaran \& Olsson, 2017). At the institutional level, neoliberal practices inform university efforts to recruit large numbers of fee-paying international students thereby generating more revenue for their institutions and government (Rea, 2016). As such, in the context of neoliberalised higher education, 'competition reigns, resources are limited, policies are market-driven, and individual worth is tied to financial and monetary profit' (Cannella \& Koro-Ljungberg, 2017, p. 156).

Such shifts also impact upon research and academics (Manathunga \& Bottrell, 2019; Olssen, 2016; Olssen \& Peters, 2005; Rousseau, 2020). First, the rise of neoliberalism signals a significant modification to research freedom. Responsibilities assigned to academics now include securing research income and subsidising their research projects and salaries (Manathunga \& Bottrell, 2019). Such expectations undermine those traditional academic principles based on academic research, open enquiry, intellectual curiosity, and discovery free of vested interest (Olssen, 2016). As researchers lose their autonomy over what is researched, their creativity is diminished, and the nature of knowledge production in universities is altered (Lingard, 2008; Olssen, 2016). Second, the focus on research productivity has served to intensify the competitive nature of the knowledge economy in higher education. This has led to 'new forms of research management that are designed to increase the speed of knowledge generation, commercialisation, and innovation' (Peters, 2015, p. 22). Inter alia, research outputs have become a key measure of institutional success as the number of publications produced by academies is linked to the limited amount of available funding from the government (Mason, 2018). Academics who are underperforming can be excluded from their academic positions. Under such pressure, academics are driven to creatively meet performance-based systems by 'gaming' techniques such as slicing up their publications into numerous units and boosting citation counts by frequent self-citation together with trading of citations with colleagues (Dougherty \& Natow, 2020, p. 466). It can be argued that the cumulative effect of the instrumental focus on research efficiency in higher education potentially undermines the nature of the research process and limits its breadth and depth.

The changes to higher education highlighted in the literature thus far also impact upon the training of research students when they work with their supervisors in a pervasive managerial and neoliberal university culture. Although there is a dearth of research on this matter, recent scholarship has highlighted a range of issues impacting upon research students studying in various countries. For example, given the increasing consumerist ethic in Scottish higher education, supervisors were found to 'over-direct' or control doctoral students' research in order to ensure their timely completion (Deuchar, 2008, p. 490). In New Zealand, international Chinese doctoral students internalised a neoliberal disposition to publish for the sake of obtaining an advantage when seeking academic positions after graduation (Huang, 2021). Furthermore, in Australia, neoliberal agendas of efficiency, profitability, and managerialism afflicted doctoral candidates by urging them to produce wide-ranging outcomes in short timeframes (Manathunga, 2019). Recent research indicates that the pressure of tight timelines intensified the anxiety of some doctoral students as they struggled to progress their research (Bosanquet et al., 2020; Shahjahan, 2020). Whilst these 
studies disclosed the nature of some research students' experiences in the neoliberalised university, they largely portrayed them as passive recipients of hegemonic neoliberalism. To the best of our knowledge, there is scant, if any, research on how HDR students question the prevalence of neoliberalism in higher education.

In sum, the neoliberalisation of higher education in general, and of academic research specifically, has been documented and contested in the literature. Nevertheless, there are limited studies concerning international research students in this regard. We argue that knowledge about the neoliberal university remains incomplete without accounting for the voices of these students - a key stakeholder group of researchers in higher education. We also contend that the enterprise of de-neoliberalising higher education (see Cannella $\&$ Koro-Ljungberg, 2017) would gain momentum from a deeper understanding of international research students' experiences of, and responses to neoliberalism. Our study contributes to this matter by working with Chinese international HDR students in Australia. To this end, we delve into these students' experiences within the neoliberalised university and their responses to the structural constraints imposed by neoliberalism. To theorise the tensions between Chinese international HDR students and their neoliberalised Australian university context, we draw on Bourdieu's sociology.

\section{A Bourdieusian perspective on neoliberalism}

Bourdieu reveals the nature of neoliberalism as a weakening state responsibility and a rising spirit of capitalism and individualism (see Calhoun, 2006, p. 1412; cited Bourdieu's original French work). In this view, the neoliberal market is a 'Darwinian world' where there is a struggle across all levels of the hierarchy (Bourdieu, 1998a, para. 9). Following Bourdieu's standpoint, Chopra (2003) discusses the pervasive nature of neoliberalism in Indian universities in response to globalisation. Our empirical work further develops this line of scholarship by using Bourdieu's concepts of habitus, doxa, field, and capital to disclose how neoliberalism as doxa has colonised the habitus of Chinese international HDR students in the Australian higher education field. Concomitantly, we examine the degree to which these students may have ventured into a competition for a relatively favourable position within that field. Furthermore, we consider whether some students may have contested the persistent, arbitrary neoliberal force as they pursue their research.

According to Bourdieu, neoliberal discourse legitimises itself as the 'scientific description of reality' (1998b, p. 94). This positioning establishes itself as doxa - taken-forgranted and unquestionable - that permeates from 'the practices and perceptions of the state and social groups (at the level of fields) to the practices and perceptions of individuals (at the level of habitus)' (Chopra, 2003, p. 421). Here, field refers to a relatively autonomous social space with its own logic of practice (Bourdieu \& Wacquant, 1992). In the context of the current study, higher education can be conceptualised as a field with a relative degree of autonomy in that it generates its own values and imperatives (Naidoo, 2004). The practices that distinguish it from other social formations, such as those in the policy and economic fields, are the pursuit of knowledge production for the public good and scoring highly in university global ranking systems. Such idiosyncratic practices to pursue symbolic excellence continue to prevail in neoliberalised higher education (Marginson, 2013). Nevertheless, no field is fully autonomous or free of other fields, and the higher education field is heteronomous of the powerful fields of economy and the state. Given the pervasive economic logic of capitalism and the state injection of such logic into 
university operations, it could be argued that the higher education field gradually loses its autonomy, and becomes reconfigured to a field with increased competition, individualism, and accountability (Olssen, 2016). When such practices are taken for granted as legitimate without the need for justification, the doxa of neoliberalism comes into being in the higher education field.

It must be noted, however, neoliberal doxa cannot be sustained within the higher education field without agents' recognition of its stakes. This is because 'the entrenchment of neoliberalism as doxa' works on the basis of agents' accepting its claims (Chopra, 2003, p. 424). To be caught up in and by the doxic neoliberalised higher education field, Chinese international HDR students may need to accept that their participation in the field is worth the effort. This is what Bourdieu (1998c, p. 79) means by referring to agents' 'ontological complicity between the habitus and the field'. By definition, habitus is a system of durable and transposable dispositions that internalises external social orders and involves a practice-structuring mechanism that operates at the nexus of the social body of agents and the social field into which agents venture or are drawn (Bourdieu \& Wacquant, 1992). Dispositions refer to the natural tendencies of social agents to take on a certain position in any field (Bourdieu \& Wacquant, 1992). In this study, Chinese international HDR students may have been enculturated into some dispositions through internalising the logic of neoliberalism prior to entering the Australian higher education field. For example, they may have acquired a disposition to publish for the sake of competition in the labour market rather than knowledge production. Such disposition is underpinned by what (Huang, 2021, p. 753) calls a 'neoliberalised publication habitus' owing to their research training in other higher education fields (such as the Chinese higher education field).

In addition to the habitus-field relation, what also needs to be considered is capital, as shown in Bourdieu's canonical sociological formula '[(habitus) (capital) + + field = practice' (Bourdieu, 1984, p. 101). Here capital refers to valued, field-specific social resources in inter-convertible economic, social, cultural, and symbolic forms, which define agents' position in a particular field (Bourdieu, 1986). Elsewhere, Chinese international HDR students are encouraged to improve their field positions through capital accrual, then to transform the neoliberalised higher education field that emphasises individual adaptation rather than system responsibility in a time of crisis (Mu, 2021a). As forthcoming in our findings, some Chinese international HDR students took issue with the neoliberal doxa in the Australian higher education field by utilising available forms of capital. We contend that in response to previous and ongoing socialisation, Chinese international HDR students develop different layers of habitus and forms of capital, which in turn enable different understandings of, and responses to the neoliberal higher education field they encounter in Australia. Our theorisation provides more weight to field, habitus, and doxa than capital owing to the empirical phenomena rendered by available data. Before we draw on Bourdieu's sociological lens to elucidate Chinese international HDR students' practice in the neoliberal Australian university, we offer a brief overview of our research design.

\section{Research design}

The paper draws from a component of a larger qualitative research project based on interviews with 18 Chinese HDR students (eight females, ten males) who have studied or completed their study in four Australian universities. Students were invited via purposive and snowball sampling by utilising our professional and social networks. The 
students who voluntarily agreed to participate in the study were asked to take part in an online semi-structured interview of 30- to 60-min duration. Interview questions centred around participants' research experiences in Australian universities. In this paper, we focus specifically on how participants negotiated the neoliberal university research environment and employ selected extracts from interview data to demonstrate our findings in this regard.

Participants were from diverse disciplinary backgrounds yet evenly distributed across social sciences $(n=6)$, natural sciences $(n=6)$, and applied sciences $(n=6)$. We acknowledge that HDR students from different disciplinary backgrounds would have both common and dissimilar learning experiences. To protect their confidentiality, pseudonyms were used, and their institutions were de-identified. The participants' demographic information is summarised in Table 1 below. Data analysis followed a thematic approach (Braun et al., 2019). After reading transcripts carefully and iteratively, initial codes were generated and reviewed followed by the identification of themes; and finally, a coding report was produced. Coding for themes was facilitated through NVIVO Version 12 . The preliminary analysis was inductive, focusing on the theme of challenges associated with neoliberalism including 'timeline', 'independence', and 'publication'. A critical interpretation of the key themes and the relevant excerpts through a Bourdieusian lens offered valuable insights into students' struggles with those challenges. In the following sections, we present findings indicative of students' encounters with a neoliberal agenda and their attempts to resist the logic of neoliberalism.

Table 1 Participant profile

\begin{tabular}{|c|c|c|c|c|c|}
\hline No & Pseudonym & Gender & Age & Major & Degree \\
\hline 1 & Mo & Male & 27 & Material Engineering & $\mathrm{PhD}$ \\
\hline 2 & Bei & Male & 26 & Environmental Engineering & $\mathrm{PhD}$ \\
\hline 3 & Lin & Female & 33 & Chemical Engineering & $\mathrm{PhD}$ \\
\hline 4 & Chen & Male & 25 & Chemical Engineering & Master \\
\hline 5 & Han & Male & 34 & Chemical Engineering & $\mathrm{PhD}$ \\
\hline 6 & Meng & Male & 32 & Chemical Engineering & $\mathrm{PhD}$ \\
\hline 7 & Jia & Female & 25 & Biology & $\mathrm{PhD}$ \\
\hline 8 & $\mathrm{Le}$ & Female & 30 & Biology & $\mathrm{PhD}$ \\
\hline 9 & Fan & Male & 31 & Hydrology & $\mathrm{PhD}$ \\
\hline 10 & Yang & Male & 29 & Biology & $\mathrm{PhD}$ \\
\hline 11 & Xin & Female & 30 & Biology & $\mathrm{PhD}$ \\
\hline 12 & Ning & Male & 25 & Chemical Engineering & Master \\
\hline 13 & Ying & Female & 38 & Education & $\mathrm{PhD}$ \\
\hline 14 & Fei & Female & 25 & Accountancy & $\mathrm{PhD}$ \\
\hline 15 & Huang & Male & 27 & Public Health & $\mathrm{PhD}$ \\
\hline 16 & $\mathrm{Su}$ & Male & 27 & Education & $\mathrm{PhD}$ \\
\hline 17 & Tang & Female & 29 & Education & $\mathrm{PhD}$ \\
\hline 18 & $\mathrm{Xi}$ & Female & 49 & Education & $\mathrm{PhD}$ \\
\hline
\end{tabular}




\section{Findings and discussion}

In the context of the neoliberal university, participants in our study demonstrated four forms of dispositions. These include dispositions of self-reliance, self-exploitation, academic publishing undergirded by a neoliberalised habitus, and a disposition of questioning neoliberalism. These findings not only revealed the significant challenges faced by participants in neoliberalised universities but also indicated their resilient responses to such challenges. We therefore use the concept of resilience to rethink participants' dispositions in our discussion. By dint of the neoliberalised habitus, participants struggled to survive and thrive in the neoliberalised Australian higher education field. Their adaptive strategies demonstrate resilience commonly defined as the process of successful coping despite significant challenges (Masten et al., 1990). With the disposition of questioning neoliberalism, some participants engaged in a sociological process of resilience which is less about individual adaption to challenge but more about probing the fundamental causes of the challenge to potentially enable transformational change (Mu, 2021b). We now present four situations, each corresponding to one of the four dispositions, noting that the disposition of academic publishing is the only one with disciplinary differences.

\section{Situation 1: Disposition of self-reliance}

As argued thus far, neoliberal imperatives now shape higher education and research training, and there is a fine line between providing support to research students and reifying the desirability of self-governance (Kloet \& Aspenlieder, 2013). In this study, participants stated they did not receive sufficient institutional and supervisory support, and thereby developed a disposition of self-reliance as illustrated below.

Access to coursework was a coveted form of institutional support for some participants $(n=5)$. Different from research students in American, Canadian, and European universities, Australian HDR students have little or no formal coursework during their candidature (Bentley \& Meek, 2018). Yet the course-free model can pose challenges, particularly to students who did not receive research methods training during their previous studies. As Xi reported, ' ... after I came to Australia, I just found it was very important to take courses... if you shift to a different direction, it would be very helpful to take courses'. Although $\mathrm{Xi}$ did not change the focus of her research, when she needed to enrol in courses on data analysis, she found there was no funding to support her requirements and had to cover the costs herself. Han and Jia reported that although they were able to take some courses at no charge, they had to go through tedious procedures to secure their enrolment. These students perceived such difficulties with a lengthy process as a means of discouraging their learning through coursework.

The above challenges Chinese HDR students experienced in accessing research training programs and related coursework are indicative of their vulnerability in the higher education marketplace. As neoliberalism continuously requires Australian universities to commercialise their higher education as a means of income, coursework is now a product sold to fee-paying students. When coupled with post-sale services, coursework is packaged to ensure these student customers enjoy the use of this higher education product. HDR students such as $\mathrm{Xi}$, Han, and Jia were excluded from the commercial model and encouraged to rely on themselves or seek help from their supervisors. However, as previously highlighted in the literature, supervisors in neoliberal universities are often preoccupied 
with meeting the conflicting demands of their workload. These academics have to take on increasing numbers of HDR candidates, teach and coordinate undergraduate and postgraduate classes, generate numerous high-quality publications, secure research grants, and engage with industries and communities (Manathunga, 2019, pp. 1228-1229).

Throughout the interviews, participants provided numerous examples of their supervisors' consistent efforts to obtain external funding, busy schedules, and heavy teaching and supervision loads. In response to limited supervision time, self-reliance becomes an essential survival skill for HDR students. As Fan reported, 'But a supervisor doesn't only supervise you. He wants you to think independently'. In this context, heavy supervision loads intensify the already crowded schedule of supervisors and further erodes the supervision time available for each student. Fan continued,

He had no feedback on the very detailed stuff, right, even if you wrote to him, because he was very, very busy, it was very difficult for him to give feedback...He didn't say he would find someone else to give you guidance, then you have to think by yourself...[I] was just forced, I would say, was compelled to be independent, because when you have no choice, you have to think by yourself.

In situations when supervisor support was unavailable or inaccessible, participants had to be self-reliant. In this context, the HDR student practice of becoming self-reliant aligned with the neoliberal logic of individual responsibilisation in time of challenge $(\mathrm{Mu}$, 2021a). In Bourdieusian terms, such alignment was underpinned by the ontological complicity between their habitus and the neoliberalised higher education field. When participants internalised the neoliberal doxa of self-reliance through habitus, they were self-perceived as being independent. In the western education context, becoming an independent scholar is indicative of building resilience, as HDR students start to bear a sense of agency, empowerment, and a belief in their capacity of overcoming challenges. However, in this context, independence also functions as a neoliberalised form of resilience through consent, self-regulation, and individual responsibilisation (Walker et al., 2006). Overemphasis on independence creates a politics of anticipation, which in turn holds individuals accountable for systemic responsibility. Underlying such resilience lies a neoliberal, dehumanising doxa that entices self-exploitation (Mu, 2021b), to which we now turn.

\section{Situation 2: Disposition of self-exploitation}

In Australia, HDR completions have marked implications for funding. According to the Department of Education, Skills, and Employment (DESE, 2017), the Research Training Program allocates grants to universities based on their relative performance in earning research income (25\%), engaging with industries and communities (25\%), and generating HDR completions (50\%). Whilst the Program encourages universities to train new generations of a research-capable workforce, it also introduces a neoliberal doxa to the higher education field, stimulating universities to compete for funding through mass production of HDR students as quickly as possible. To streamline mass production, universities use milestones for quality control of their HDR products. Although milestones may differ across universities, they have key features of standardisation, accountability, and performativity. When HDR students internalise such neoliberal doxa within the higher education field, they may develop a disposition of self-exploitation. In this study, participants all confided that they had experienced excessive pressure and anxiety in order to pass each milestone and meet the required deadline. As Tang reflected, 
When it came to the final milestone, during the last month, I was really 'burned', because I was like, 'Oh, my God, I'm not going to finish this.'... During the last month, it was hard to endure the feeling of hastiness and urgency. Every day, I got up at 5 a.m. and went home at 11 p.m. or midnight. I sat in front of the computer in the office and kept typing without stopping. I was exhausted...I think I almost collapsed and couldn't bear it anymore.

Xin shared a similar experience, 'It was a very exhausting time, and I was really worried that I was going to die because I wasn't getting enough sleep'. In addition, the tight research schedule reportedly encroached on social activities. As Fan noted,

I don't try to maintain a good relationship with my colleagues, because I have spent all my energy on research. In our group, basically you don't care about other things, you just need to focus on your research.

Mo echoed, 'we usually just say hello and have a simple chat. We don't have many conversations as we don't have time'. Apart from the loss of social connection, working overtime also posed threat to mental health and wellbeing, as reported by participants like Lin, who recalled,

During my second year of PhD, I was so stressed that I couldn't sleep for almost half a year, and then I had a mental breakdown, and sometimes I felt hallucinated. I found my hair turned grey and was falling out at that time.

In a higher education field fraught with the neoliberal doxa of performativity and accountability for quality and timelines, research students are expected to complete their thesis and yield knowledge consistent with standardised milestones. Yet such dominant, imposed logic ignores the fact that research and life in general are inherently unpredictable (Manathunga, 2019). What appears to count is how quickly candidates can be processed through the HDR system irrespective of unexpected disruptions and interruptions to the research journey. This overlooks the fact that the depth and sophistication of research which contributes to the formation of original knowledge takes time to achieve. Pressure to complete within fixed research timelines can create significant practical difficulties and cause emotional challenges to international HDR students who are already pressed by time-limited scholarships and visa requirements. As shown in our data, participants lamented physical and mental challenges together with social isolation as they worked long hours to meet such deadlines.

Interview data from some participants revealed that consistent hard work helped them to meet deadlines and pass milestones. Through such relentless work, they were able to successfully adapt to the neoliberal context of the HDR system. In other words, pervasive neoliberalism pushed students to become resilient. However, it could also be argued that such resilience in the face of neoliberalism was obtained through selfexploitation. According to Evans and Reid (2015, p. 154), such neoliberalised resilience can also be viewed as a form of subjugation,

Our journey across the resilience terrain forced us to appreciate the hidden depth of its nihilism, the pernicious forms of subjugation it burdens people with, its deceitful emancipatory claims that force people to embrace their servitude as though it were their liberation, and the lack of imagination the resiliently minded possess in terms of transforming the world for the better. We too have become exhausted by its ubiquitous weight and the chains it places around all our necks. 
Whilst we agree with Evans and Reid (2015) that resilience — when neoliberalised barely transforms the social world, some of our participants $(n=7)$ resiliently took issue with neoliberalism rather than falling prey to it. Before we turn to this form of resilience in the last analysis section, we present and analyse the disposition of academic publishing a practice widely discussed in extant literature.

\section{Situation 3: The 'floating' publication habitus}

The adage 'publish or perish' prevails in universities globally, and research students often internalise the external pressure of academic publishing through competing habituses. An example of this is 'the neoliberal publication habitus' driven by the logic of 'knowledge production as a commodity for sale', whilst less obvious yet co-existing is the 'humanising publication habitus' for the sake of knowledge sharing and public good (Huang, 2021, p. 753). In our study, participants appeared to demonstrate a neoliberal publication habitus in their efforts to prove their research capacity through academic publishing and to obtain the accredited capital required for post-graduation employment in the higher education field. However, their aims to achieve publication outcomes were not always favoured or supported by the Australian higher education system. In what follows, we draw from our findings to discuss the floating publication habitus of Chinese international HDR students.

In Australia, most HDR students obtain their degree through thesis by monograph, supplemented by other approaches such as thesis by publication and thesis by creative works (TEQSA, 2021). Sixteen out of 18 participants in our study were completing or have completed their HDR study through thesis by monograph. As thesis by monograph is the requirement for graduation, other academic work, publications included, may become less important. Some participants $(n=4)$ from natural sciences and applied sciences noted that their supervisors may require or suggest and assist them to produce a certain number of publications apart from the completion of the thesis. However, those from social sciences $(n=5)$ were barely supported to publish by their supervisors. A recently completed doctoral student Xi, from the Faculty of Education, shared her supervisor's attitudes,

But in general, she did not actively push me (to publish), and her plan was always that you should write your thesis first. I don't know, but someone, later others told me, in fact, the best way to publish is that your supervisor urges you to publish your paper during your $\mathrm{PhD}$. Otherwise, you will be very embarrassed when you seek a job. I noticed that too, but that was not how she did it. She kept saying you finish the thesis first.

Su perceived the reasons behind supervisors' disinterest in supporting student publication as twofold. He noted first that supervisors may not be aware that publication often plays a decisive role in the fierce employment competition faced by Chinese HDR students if they aim to secure an academic position in China. Second, Su reflected that even with a certain level of awareness of the Chinese situation, supervisors may not assume it is their responsibility to support student publication because there is no need to as for the case of thesis by monograph. In stark contrast, Chinese universities and supervisors stress the importance of student publication as this is a requirement for graduation. As Meng noted,

Regarding the graduation criteria, there may be some corresponding requirements for research achievement in Chinese universities, which is strictly quantified. For example, as far as I know, no matter whether it's the institutional or the potential requirements, you have to publish a certain number of articles, then you can graduate. 
In this vein, Chinese international HDR students can be placed at a disadvantage as they become less competitive in the labour market due to their lack of publications when compared with their locally educated peers.

Conjointly, the data point to a paradox: on the one hand, there is no doubt that supervisors in Australian universities value research and thesis quality, and thereby, guide students to invest time as much as possible in monograph writing. On the other, the logic of Australian supervisory practice without accompanying publication expectations can be questioned given that it renders Chinese international HDR students unsupported in meeting the publishing requirements of Chinese universities. This is because many of these students had already developed a practical sense of the requirement to publish during their previous academic experience in the Chinese or related higher education field. The paradox raised above is intensified, given that these students' publication habitus can be sustained in Australia due to its enduring presence or durability. The 'structural lag' (Bourdieu, 1977, p. 83) or 'hysteresis effect' (Bourdieu, 1977, p. 78) may give rise to a disjuncture between participants' publication habitus and the Australian higher education field which may not always support such habitus.

According to Bourdieu (1990), habitus can be 'objectively adjusted to the logic characteristic of a particular field' (pp. 55-56). Yet this is not the case for our participants as their publication habitus did not diminish altogether, despite being exposed to the Australian higher education field that may not support it. This may be attributed to the participants' imagined future in the Chinese higher education field or other fields that construct the basis or footing of the publication habitus. Without such imagination, such habitus would fade over time. We therefore argue that the prescient desire of the participating Chinese HDR students to publish proactively reinforced the publication habitus in Australia prior to their return to the Chinese or other higher education field which values that habitus. Put simply, the aspiration for academic employment made it possible for participants to shape their habitus beyond time and field.

In this respect, Chinese students' publication habitus does not abate but remains prescient or floating, even though the supervisory practices of some academics in the Australian higher education field may suspend that habitus. The term 'floating' conveys transience, vulnerability, and dislocation. It has been employed in the literature to refer to the predicament and precarity of large numbers of unskilled Chinese adults moving from the less developed regions (often rural) of China to developed regions (often urban) in search of employment (Chen \& Liang, 2007). Their accompanying children face layers of structural constraints when accessing social welfare in urban space such as free public schooling and are referred to as floating children (see $\mathrm{Mu}, 2018$ ). Informed by this literature, we draw from Bourdieu's theory and craft the concept of a floating habitus that is not the product of the current field but one of both previous and prospective fields. Rooted in the previous field (for example, the Chinese higher education field), this habitus is dislodged when agents enter the current field (for instance, the Australian higher education field) and is reinforced due to agents' aspiration for entering the prospective field (upon return to Chinese higher education field). The notion of floating habitus can effectively account for habitus-field disjuncture at an empirical level and extends Bourdieu's concept of habitus to theorise the nuanced and dynamic practices across fields and over time.

\section{Situation 4: The de-neoliberalising disposition}

Neoliberalism is a commanding hegemony that has 'saturated our consciousness, so that the educational, economic and social world we see and interact with, and the commonsense 
interpretations we put on it becomes...the only world' (Apple, 2019, p. 4). The process of creating hegemony is not a conscious conspiracy perpetrated by all those who act following hegemonic principles, but instead, is an often hidden process, to which actors most unknowingly adapt (Saunders, 2007). In Bourdieusian terms, neoliberalism informs perceptions and actions through habitus. In situations 1, 2, and 3, we analysed participants' dispositions of self-reliance, self-exploitation, and academic publishing, all of which were underpinned by a neoliberalised habitus. Paradoxically, participants' resilience to the challenges brought about by neoliberalism can be seen in terms of a complicit or hidden alignment between habitus and neoliberalism. Yet in situation 4, some participants $(n=7)$ displayed reflections, actions, and practices that questioned and rejected the doxa of neoliberalism within the Australian higher education field.

As noted earlier, most $(n=16)$ participants reported being unable to escape from the pressure of required time constraints for the completion of their studies. Interestingly, Han and Su shared their critical responses towards 'timeline' and 'pace'. $\mathrm{Su}$, a second-year $\mathrm{PhD}$ student, argued that research should not be evaluated by 'speed',

There is no saying like 'I'm fast'. We should never evaluate according to speed, you are too fast or too slow. [We] only say in terms of your progress, your research is good or not good, it is about the progress, the overall situation of your research is good or not. Just 'being fast', that's not our goal.

Su also spoke about the possibility of an 'extension to milestone' and considered 'extension' as neutral instead of negative. As he reflected, an 'extension was a particular moment of a research journey, which means you merely required more time to finish your project'. Han, in his third year, usually worked at his own pace, noting, 'everyone's research project is different, and I don't have to keep a close eye on their (his HDR peers') pace'. Here both $\mathrm{Su}$ and Han demonstrated a certain level of emancipation from the neoliberal agenda, and freed themselves, at least to a certain degree, from the standardised timeline during their research journey. We construe their strategic emancipation as resilience to neoliberalism.

A closer analysis of data indicates that resilience to neoliberalism does not necessarily spring from within. Rather, it can be empowered by supervisors. Such empowerment is a form of social capital, that is, the aggregate of actual or potential recourses available through networking with significant others (Bourdieu, 1986), in the case of the current study, the supervisors. For example, Bei, from a Faculty of Environment Engineering, once felt concerned that a certain experiment had taken a longer time than expected and wished to offset the 'wasted' time by working longer hours. As shown in situation 2, many $(n=9)$ participants would turn to a 'self-exploitation' approach by sacrificing their private time and working overtime to meet the timeline by any means. However, Bei's supervisor discouraged him from doing so. Instead of working overtime, the supervisor advised Bei to manage his time wisely and effectively. This advice may not ensure Bei is free of the pressure of timelines, but it functioned as social capital that mitigated Bei's anxiety caused by timeline pressures and prevented him from excessive self-exploitation.

In addition, supervisors' attitudes towards publication also impacted upon students' neoliberal publication habitus. Rather than pursuing quantity of publication to compete for a better position in the neoliberal university, Han reported his supervisor's high standards on publications,

...the good point of our supervisor is that he has very high requirements for publishing articles. Because in our field, many people just publish one 'point'.... Our supervisor calls for a full story, not just one point. You need to do systematic research, and 
then he asks you to publish an article...I think his approach is great. I don't necessarily pursue quantity; quality is very important. My supervisor cares a lot about his research reputation, and his articles are all relatively in high quality.

Here social capital enabled an intergenerational transmission of habitus, a humanising publication habitus for the sake of scholarship (Huang, 2021). This empowering transmission shifted students' neoliberal publication habitus through everyday HDR supervision. This is what Bourdieu (2000, p. 172) implies by 'a thoroughgoing process of countertraining' that involves 'repeated exercises...to durably transform habitus'. Meng's experiences also revealed such habitus transformation,

...to a varying degree, my thinking pattern has been altered. (I would) pay more attention to the research project, less attention to publications, because publications may function as a quantitative indicator on some level, but it is not an indicator that can measure your research level.

The findings above show evidence of resilience to the hegemony of neoliberalism and reconstruction of a research-oriented rather than neoliberalised habitus. Such resilience and reconstruction may not succeed without social capital, supervisory empowerment in this case.

\section{Conclusion}

In this paper, we analysed data from interviews with 18 Chinese international HDR students using Bourdieu's framework to understand their research experiences in neoliberalised Australian universities. Grounded in such experiences was the pervasive doxa of neoliberalism in the Australian higher education field entangled with a market-driven logic emphasising performance measurement and individual responsibilisation. Chinese international HDR students were thereby drawn into a predicament where they had to independently deal with limited support, accelerated research workload, and intensified competition within the higher education field. Meanwhile, they were enculturated into a floating habitus of academic publishing to negotiate the tensions across fields and over time. In order to grapple with such predicaments, these students gradually developed intensified dispositions of self-reliance and self-exploitation. However, their journeys to becoming independent researchers were also accompanied by sacrificing their wellbeing and mental health. As Davies and Bansel (2007, p. 258) lament, it is no simple task to become an appropriate(d) neoliberal subject who floats free of the social and assumes responsibility for its own survival in a competitive world where only the fittest survive.

Interestingly, some Chinese international HDR students and their supervisors sustained at least a certain degree of freedom in the face of the doxic neoliberalism, rather than succumbing to it or rendering it as integral to their habitus. Such resistant students may have to face the possibilities of loss of future opportunities, resources, and recognition in the neoliberal university. Yet their tenacious researcher spirit, one that values knowledge and scholastic integrity, sustained them in their attempts to emancipate research from the constraints of neoliberalism. We theorise this as a form of sociology of resilience. That is, rather than adapting to the neoliberal doxa in the higher education field, these students took issue with it. In this way, the Chinese international HDR students' sociological otherness of resilience constitutes a heterodox force in opposition to the orthodox direction of the neoliberal university. Such resilient demeanours are in alignment with Bottrell and Manathunga (2019, p. 
ix) who write, 'knowledge produced within universities should above all serve in the interest of our humanity' and 'must courageously set our sights toward reinventing the praxis of teaching and research within higher education' in combat to the pervasive impact of the neoliberal university.

Recently, Cannella and Koro-Ljungberg (2017, p. 156) posed two important questions, namely, 'Do we recognise when these neoliberal agenda are imposed?' and 'how can we rethink, reconceptualise, act, and react within higher education to challenge and even demolish neoliberalism?'. Some of our Chinese international HDR student participants responded powerfully to these difficult questions and convincingly showed that the task of de-neoliberalisation is not impossible, but rather achievable. Informed by our findings, we hope that HDR students, their supervisors, and staff in the higher education sector in general are not necessarily neoliberalised bodies but potentially reflexive knowledge workers with collective resilience to neoliberalism. To enable and empower HDR students to question the taken-for-granted neoliberal doxa within the higher education field, we echo Deuchar (2008) who proposes a less utilitarian and more critically reflexive view of HDR training. We also acknowledge Manathunga (2019), who points to developing a more inclusive and inventive systems of HDR education rather than regarding those who fail to follow the standardised timeframe as incompetent. We contend that the Australian government and higher education institutions should accept their responsibilities to provide international HDR students with sufficient resources to complete their research studies. Moreover, they need to acknowledge that universities must be supported in pursuing research and high-quality HDR supervision beyond the demands and limitations of the marketplace. A de-neoliberalised HDR education provides an opportunity to disrupt the production of homo economicus and cultivate neo-homo academicus within the global academy in the pursuit of truth and knowledge whilst supporting the wellbeing of international students as they pursue their studies.

Author contribution All authors contributed to the study conceptualisation and design. Material preparation and data collection were completed by Congcong Xing. The three authors collaboratively analysed the data and wrote the manuscript. All authors read and approved the final manuscript.

Funding The work of the first author is supported by the Australian Government Research Training Program (RTP) scholarship. The work of the second author is sponsored by the Australian Research Council (DE180100107).

\section{Declarations}

Conflict of interest The authors declare no competing interests.

\section{References}

Apple, M. W. (2019). Ideology and curriculum (Fourth ed.). Routledge.

Basaran, T., \& Olsson, C. (2017). Becoming international: On symbolic capital, conversion and privilege. Millennium, 46(2), 96-118. https://doi.org/10.1177/0305829817739636

Bentley, P. J., \& Meek, V. L. (2018). Development and future directions of higher degree research training in Australia. In Doctoral education for the knowledge society (pp. 123-146). Springer.

Bosanquet, A., Mantai, L., \& Fredericks, V. (2020). Deferred time in the neoliberal university: Experiences of doctoral candidates and early career academics. Teaching in Higher Education, 25(6), 736-749. https://doi.org/10.1080/13562517.2020.1759528 
Bottrell, D., \& Manathunga, C. (2019). Resisting neoliberalism in higher education-Volume I Seeing through the cracks. Palgrave Macmillan.

Bourdieu, P. (1977). Outline of a theory of practice (R. Nice, Trans.). Cambridge University Press.

Bourdieu, P. (1984). Distinction: A social critique of the judgment of taste (R. Nice, Trans.). Routledge \& Kegan Paul Ltd.

Bourdieu, P. (1986). The forms of capital. In J. G. Richardson (Ed.), Handbook of theory and research for the sociology of education (pp. 241-258). Greenwood Press.

Bourdieu, P. (1990). The logic of practice (R. Nice, Trans.). Polity Press.

Bourdieu, P. (1998a). The essence of neoliberalism: Utopia of endless exploitation. LE MONDE DIPLOMATIQUE, December. Retrieved 07/05/2021 from https://mondediplo.com/1998/12/08bourdieu

Bourdieu, P. (1998b). Neoliberalism, the utopia (becoming a reality) of unlimited exploitation. In Acts of resistance: Against the tyranny of the marke) (pp. 94-105). The New Press.

Bourdieu, P. (1998c). Practical reason: On the theory of action. Stanford University Press.

Bourdieu, P. (2000). Pascalian meditations (R. Nice, Trans.). Polity Press.

Bourdieu, P., \& Wacquant, L. J. D. (1992). An invitation to reflexive sociology. University of Chicago Press.

Braun, V., Clarke, V., Hayfield, N., \& Terry, G. (2019). Thematic analysis. In P. Liamputtong (Ed.), Handbook of research methods in health social sciences (1st ed., pp. 843-860). Springer. https:// doi.org/10.1007/978-981-10-5251-4

Calhoun, C. (2006). Pierre Bourdieu and social transformation: Lessons from Algeria. Development and Change, 37(6), 1403-1415. https://doi.org/10.1111/j.1467-7660.2006.00535.x

Cannella, G. S., \& Koro-Ljungberg, M. (2017). Neoliberalism in higher education: Can we understand? Can we resist and survive? Can we become without neoliberalism? Cultural Studies $\leftrightarrow$ Critical Methodologies, 17(3), 155-162.

Chen, Y. P., \& Liang, Z. (2007). Educational attainment of migrant children: The forgotten story of China's urbanization. In E. Hannum \& A. Park (Eds.), Education and reform in China (pp. 134-149). Routledge.

Chopra, R. (2003). Neoliberalism as doxa: Bourdieu's theory of the state and the contemporary Indian discourse on globalisation and liberalization. Cultural Studies, 17(3-4), 419-444. https://doi.org/ 10.1080/0950238032000083881

Davies, B., \& Bansel, P. (2007). Neoliberalism and education. International Journal of Qualitative Studies in Education, 20(3), 247-259. https://doi.org/10.1080/09518390701281751

DESE. (2015). China infographic 2015. Retrieved 25/05/2021 from https://internationaleducation.gov. $\mathrm{au} / \mathrm{research} /$ research-snapshots/Documents/China\%20Infographic\%202015.pdf

DESE. (2017). Calculating the Research Training Program grant amounts. Retrieved 25/05/2021 from https://www.dese.gov.au/download/10396/calculating-research-training-program/21040/calculating-research-training-program/pdf

DET. (2019). Education export income by country 2018-19. Retrieved 17/03/2021 from https://inter nationaleducation.gov.au/research/Research-Snapshots/Documents/Export\%20Income\%202018\% E2\%80\%9319\%20Country\%20Infographic.pdf

Deuchar, R. (2008). Facilitator, director or critical friend?: Contradiction and congruence in doctoral supervision styles. Teaching in Higher Education, 13(4), 489-500. https://doi.org/10.1080/13562 510802193905

Dougherty, K. J., \& Natow, R. S. (2020). Performance-based funding for higher education: How well does neoliberal theory capture neoliberal practice? Higher Education, 80(3), 457-478. https://doi. org/10.1007/s10734-019-00491-4

Evans, B., \& Reid, J. (2015). Exhausted by resilience: Response to the commentaries. Resilience (Abingdon, U.K.), 3(2), 154-159. https://doi.org/10.1080/21693293.2015.1022991

Giroux, H. A. (2015). Dangerous thinking in the age of the new authoritarianism. Paradigm Publishers.

Huang, Y. (2021). Doctoral writing for publication. Higher Education Research and Development, 40(04), 753-766. https://doi.org/10.1080/07294360.2020.1789073

Kenny, J. (2018). Re-empowering academics in a corporate culture: An exploration of workload and performativity in a university. Higher Education, 75(2), 365-380. https://doi.org/10.1007/ s10734-017-0143-z

Kloet, M. V., \& Aspenlieder, E. (2013). Educational development for responsible graduate students in the neoliberal university. Critical Studies in Education, 54(3), 286-298. https://doi.org/10.1080/ 17508487.2013 .826706

Lingard, B. (2008). Globalising research accountabilities. Access: Critical Perspectives on Communication, Cultural and Policy Studies, 27(1/2), 175-188. 
Manathunga, C. (2019). 'Timescapes' in doctoral education: The politics of temporal equity in higher education. Higher Education Research and Development, 38(6), 1227-1239. https://doi.org/10. 1080/07294360.2019.1629880

Manathunga, C., \& Bottrell, D. (2019). Resisting neoliberalism in higher education-Volume II Prising open the cracks (1st ed.). Palgrave Macmillan. https://doi.org/10.1007/978-3-319-95834-7

Marginson, S. (2013). The impossibility of capitalist markets in higher education. Journal of Education Policy, 28(3), 353-370. https://doi.org/10.1080/02680939.2012.747109

Mason, S. (2018). Publications in the doctoral thesis: Challenges for doctoral candidates, supervisors, examiners and administrators. Higher Education Research and Development, 37(6), 1231-1244. https://doi. org/10.1080/07294360.2018.1462307

Masten, A. S., Best, K. M., \& Garmezy, N. (1990). Resilience and development: Contributions from the study of children who overcome adversity. Development and Psychopathology, 2(4), 425-444. https:// doi.org/10.1017/S0954579400005812

Monbiot, G. (2017). Out of the wreckage: A new politics for an age of crisis. Verso.

Mu, G. M. (2018). Building resilience of floating children and left-behind children in China: Power, politics, participation, and education (1st ed.). Taylor and Francis.

Mu, G. M. (2021a). Resiliency and responsibilisation: The case of international PhD candidates-in-waiting. PESA Agora. Retrieved 09/03/2021 from https://pesaagora.com/columns/resiliency-and-responsibilisat ion/

$\mathrm{Mu}$, G. M. (2021b). Sociologising resilience through Bourdieu's field analysis: Misconceptualisation, conceptualisation, and reconceptualisation. British Journal of Sociology of Education, 42(1), 15-31. https://doi.org/10.1080/01425692.2020.1847634

Naidoo, R. (2004). Fields and institutional strategy: Bourdieu on the relationship between higher education, inequality and society. British Journal of Sociology of Education, 25(4), 457-471. https://doi.org/10. $1080 / 0142569042000236952$

Olssen, M. (2016). Neoliberal competition in higher education today: Research, accountability and impact. British Journal of Sociology of Education, 37(1), 129-148. https://doi.org/10.1080/01425692.2015. 1100530

Olssen, M., \& Peters, M. A. (2005). Neoliberalism, higher education and the knowledge economy: From the free market to knowledge capitalism. Journal of Education Policy, 20(3), 313-345. https://doi.org/10. $1080 / 02680930500108718$

Peters, M. A. (2015). The university in the epoch of digital reason: Fast knowledge in the circuits of cybernetic capitalism. In P. Gibbs, O. H. Ylijoki, C. Guzmán-Valenzuela, \& R. Barnett (Eds.), Universities in the flux of time (pp. 9-31). Routledge.

Rea, J. (2016). Critiquing neoliberalism in Australian universities. Australian Universities' Review, 58(2), 9-14.

Rousseau, N. (2020). The sociological imagination, neoliberalism, and higher education. Social Currents, 7(5), 395-401. https://doi.org/10.1177/2329496520912735

Saunders, D. (2007). The impact of neoliberalism on college students. Journal of College and Character, 8(5). https://doi.org/10.2202/1940-1639.1620

Shahjahan, R. A. (2020). On 'being for others': Time and shame in the neoliberal academy. Journal of Education Policy, 35(6), 785-811. https://doi.org/10.1080/02680939.2019.1629027

TEQSA. (2021). Higher Education Standards Framework (Threshold Standards) 2021. Retrieved 13/08/2021 from https://www.teqsa.gov.au/higher-education-standards-framework-2021

Walker, C., Gleaves, A., \& Grey, J. (2006). Can students within higher education learn to be resilient and educationally speaking, does it matter? Educational Studies, 32(3), 251-264.

Welch, A. (2012). Opportunistic entrepreneurialism and internationalisation of higher education: Lessons from the antipodes? Globalisation, Societies and Education, 10(3), 295-315. https://doi.org/10.1080/ 14767724.2012.710119

Publisher's note Springer Nature remains neutral with regard to jurisdictional claims in published maps and institutional affiliations. 